\title{
Coordination Polymer of Cobalt (II) Nitrate with Imidazole: Synthesis, Properties and Crystal Structure
}

\author{
Elmira Alamanova1, Nasira Shyytyeva1, Zhyldyz Berdalieva1,2, Nurzat Abdyldaeva², \\ Astra Duishonbaeva3 ${ }^{3}$, Zhypargul Abdullaeva4* ${ }^{*}$
}

${ }^{1}$ Institute of Chemistry and Phytoechnologies, Kyrgyz National Academy of Sciences, Bishkek, Kyrgyzstan

${ }^{2}$ Department of Biochemistry and General Bioorganic Chemistry, Kyrgyz State Medical Academy, Bishkek, Kyrgyzstan

${ }^{3}$ Department of Chemistry and Chemical Technology, Kyrgyz National University named after Z. Balasagyn, Kyrgyzstan

${ }^{4}$ Science and Research Department, Osh State University, Osh, Kyrgyzstan

Email: *jypar.science@oshsu.kg

How to cite this paper: Alamanova, E., Shyytyeva, N., Berdalieva, Z., Abdyldaeva, N., Duishonbaeva, A. and Abdullaeva, Z. (2021) Coordination Polymer of Cobalt (II) Nitrate with Imidazole: Synthesis, Properties and Crystal Structure. Journal of Crystallization Process and Technology, 10, 1-9. https://doi.org/10.4236/jcpt.2021.101001

Received: December 3, 2020

Accepted: January 25, 2021

Published: January 28, 2021

Copyright $\odot 2021$ by author(s) and Scientific Research Publishing Inc. This work is licensed under the Creative Commons Attribution International License (CC BY 4.0).

http://creativecommons.org/licenses/by/4.0/

\section{(c) (i) Open Access}

\begin{abstract}
Layered metal-organic polymer $\left[\mathrm{Co}(\mathrm{L})_{6}\right]\left(\mathrm{NO}_{3}\right)_{2}$ was obtained (where, $L=$ $\mathrm{C}_{3} \mathrm{H}_{4} \mathrm{~N}_{2}$ ) and structurally characterized by X-Ray diffraction (XRD) analysis.

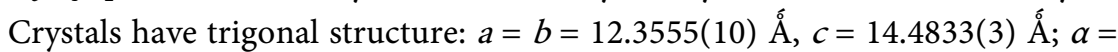
$\beta=90^{\circ} ; \gamma=120^{\circ} ; V=1914.78(5) \AA ์ ; \mathrm{R} 3, Z=3$. The structure of the complex consists of discrete $\left[\mathrm{Co}(\mathrm{L})_{6}\right]^{2+}$ cations and $\mathrm{NO}_{3}^{-}$anions. The $\mathrm{Co}^{2+}$ ion has a centrosymmetric octahedron configuration with a coordination site- $\mathrm{CoN}_{6}$. The ligand is coordinated monodentate through the pyridine nitrogen atom (N3) to the $\mathrm{Co}^{2+}$ ion with an average Co-N bond distance of 2.1590 Á. Molecules in the coordination polymer are additionally linked by intermolecular hydrogen bonds through the pyrrole nitrogen atom $(-\mathrm{N}-\mathrm{H})$ and oxygen of the nitrate group with the formation of a polymer chain of the type: N-H...O. The chains are linked in layers along the (001) plane.
\end{abstract}

\section{Keywords}

Metal-Organic Polymer, Crystal Structure, Coordination, Cobalt Nitrate, Imidazole

\section{Introduction}

Metal-organic coordination polymers of the compound of 3d-metals with multidentate ligands can be considered as precursors for the creation of organic hybrid materials. The increased attention to such compounds is associated with 
their unusual structures and the possibility of obtaining multifunctional materials on their basis. The latter should include magnetoactive [1], luminescent [2], sorption [3] and bioactive [4] properties.

The preparation of coordination polymers of various types (linear, chain, layered, framework) [5] depends on many factors, such as the coordination preference of metals, geometric characteristics of organic ligands, the nature of counterions, etc. Among the ligands suitable for the synthesis of compounds with the above-mentioned properties, such a ligand likes an imidazole containing two different nitrogen atoms: pyridine and pyrrole. Consequently, imidazole can act as both a chelating and a bridging ligand [6]. In addition, imidazole can participate in the formation of hydrogen bonds through the $-\mathrm{N}-\mathrm{H}$ groups of imidazole with the counter ion $\left(\mathrm{NO}_{3}^{-}\right)$, creating supramolecular assemblies.

This work presents the results of synthesis, IRS, DTG, X-ray structural analysis of the layered metal-organic polymer $\left[\mathrm{Co}(\mathrm{L})_{6}\right]\left(\mathrm{NO}_{3}\right)_{2}(\mathrm{I})$.

\section{Experimental}

We used the reagents $\mathrm{Co}\left(\mathrm{NO}_{3}\right)_{2} \cdot 6 \mathrm{H}_{2} \mathrm{O}$ (reagent grade) imidazole (Sigma Aldrich, 99.5\%). The complex was obtained by the interaction of cobalt nitrate with imidazole according to the well-known method [7]. The compound is crystals of light lilac color, stable in air, Tm. $=238^{\circ} \mathrm{C}$.

Elemental analysis of the complex:

Found\%: $\mathrm{C}=35.05 ; \mathrm{H}=3.89 ; \mathrm{N}=32.08 ; \mathrm{Co}=9.11$.

Calculated\%: $\mathrm{C}=36.52 ; \mathrm{H}=4.05 ; \mathrm{N}=33.14 ; \mathrm{Co}=9.96$.

Elemental analysis was performed on an EA-3000 elemental analyser (EuroVector). IR spectra of the ligand and the synthesized complex (I) were recorded in tablets on a Nicolette Avatar spectrophotometer in the range of $400-4000$ $\mathrm{cm}^{-1}$. The thermogram of the compound was recorded on a Paulik-Paulik-Erdey system derivatograph in an air atmosphere when heated from $20^{\circ} \mathrm{C}$ to $1000^{\circ} \mathrm{C}$ at a heating rate of 10 degree per minute. Alumina $\left(\mathrm{Al}_{2} \mathrm{O}_{3}\right)$ served as the standard. $\mathrm{X}$-ray structural analysis of the crystal was carried out at a temperature of $100 \mathrm{~K}$ on a Bruker Quest D8 diffractometer equipped with a Photon-III detector and a water-cooled X-ray tube $(30 \mathrm{~mA}, 50 \mathrm{kB}, \lambda(\mathrm{MoK} \alpha)=0.71073 \AA \AA$, graphite monochromator, $\varphi$ - and $\omega$-scanning, step $0.35^{\circ}$, exposure time $2 \mathrm{sec}$ ). Registration of reflections and establishment of the structure was carried out in the APEX software [8] package III. The reflection intensities were integrated using the SAINT program [9]. The reflection intensities were corrected to take into account the absorption of radiation by the crystal using the SADABS program [10] semiempirically using equivalent reflections. The space group is determined using statistics of systematically absent reflections. The structure was solved by a direct method using SHELXT [11]. The positions of all atoms were found from the difference electron density map. The structure was refined by the least squares method in the anisotropic (for hydrogen atoms-isotropic) full matrix approximation in F2 in the SHELXL-2018 program [12]. SHELXTL software package is used to visualize the structure. 


\section{Results and Discussions}

The main crystallographic data and the results of structure refinement are given in Table 1, the main bond lengths and bond angles are in Table 2, and the structure of the complex is shown in Figure 1.

The thermal behavior of the free ligand (Figure 2) and the complex (Figure 3) was studied by the derivatographic method with recording the TG curve. Several thermal manifestations are observed on the DTA curve of the ligand: endothermic $-65^{\circ} \mathrm{C}, 75^{\circ} \mathrm{C}, 215^{\circ} \mathrm{C}$ and exothermic effect at $360^{\circ} \mathrm{C}$, which correspond to the removal of adsorbed moisture, melting, decomposition and burnout of the organic part.

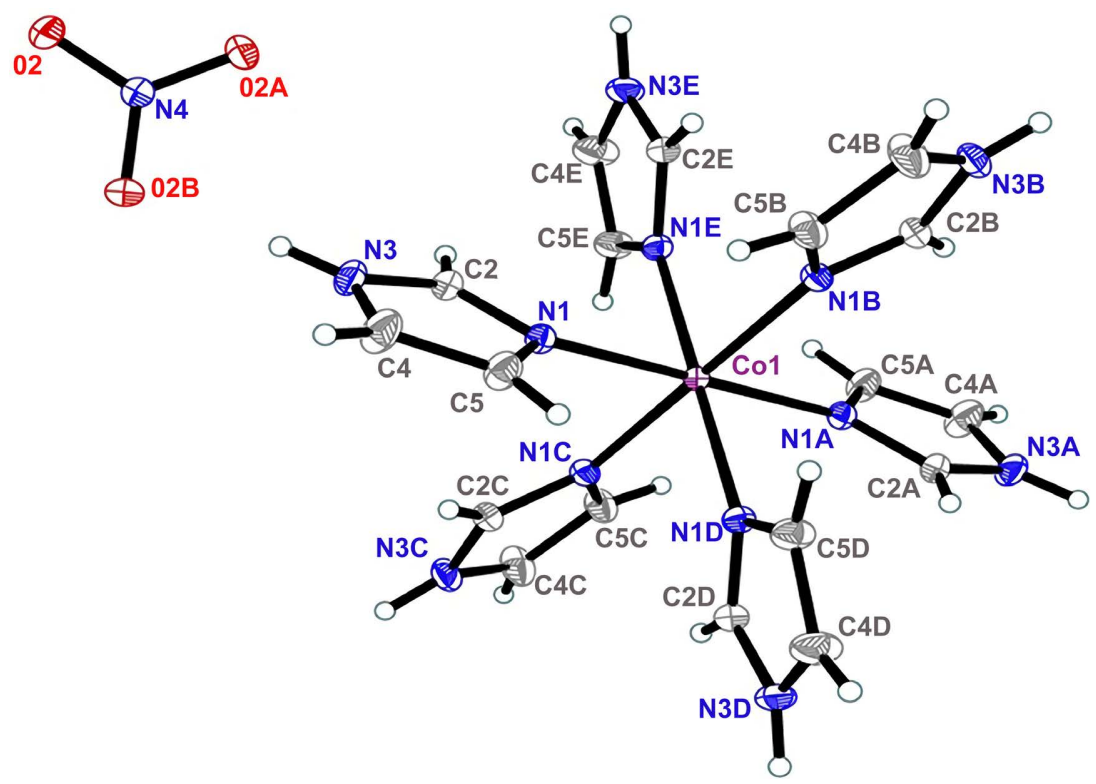

Figure 1. The structure of $\left[\mathrm{Co}(\mathrm{L})_{6}\right]^{2+}$ cation complex.

Table 1. Crystallographic characteristics, details of the experiment and refinement of the structure of the compound $\left[\mathrm{Co}(\mathrm{L})_{6}\right]\left(\mathrm{NO}_{3}\right)_{2}$.

\begin{tabular}{cc}
\hline Parameter & Value \\
\hline Molecular folrmula & {$\left[\mathrm{Co}\left(\mathrm{C}_{3} \mathrm{H}_{4} \mathrm{~N}_{2}\right)_{6}\right]\left(\mathrm{NO}_{3}\right)_{2}$} \\
Brutto formula & $\mathrm{C}_{18} \mathrm{H}_{24} \mathrm{CoN}_{14} \mathrm{O}_{6}$ \\
Molecular mass & 591.44 \\
$\mathrm{~T}, \mathrm{~K}$ & 100 \\
Syngony & Trigonal \\
Space group & $\mathrm{R}-3$ \\
Unit cell parameters: & \\
$a, \AA$ & $12.3555(10)$ \\
$b, \AA$ & $12.3555(10)$ \\
$c, \AA$ & $14.4833(5)$ \\
$\alpha$ (degree) & 90 \\
$\beta$ (degree) & 90 \\
\hline
\end{tabular}




\section{Continued}

\begin{tabular}{cc}
\hline (degree) & 120 \\
$V, \AA^{3}$ & $1914.78(5)$ \\
$Z$ & 3 \\
$\mathrm{P}($ calc. $), \mathrm{g} / \mathrm{cm}^{3}$ & 1.539 \\
$2 \theta$ region (min, max) deg. & $2.367-33.150$ \\
Index range & 18563 \\
Number of measured reflections & $1625[\mathrm{Rint}=0.0273]$ \\
Number of independent reflections & $1625 / 76$ \\
Data/adjustable parameters & 1.083 \\
$600 \mathrm{~F}-$ no $\mathrm{F}^{2}$ & $\mathrm{R} 1=0.0233, \mathrm{WR} 2=0.0670$ \\
$\mathrm{R}$ indices $\mathrm{Y} \geq 26(\mathrm{Y})$ & $\mathrm{R} 1=0.0239, \mathrm{WR} 2=0.0676$ \\
$\mathrm{R}$ indexes or all data & $0.556-0.478$ \\
$\Delta \rho_{\max }, \Delta \rho_{\min }, \mathrm{e} / \AA^{3}$ &
\end{tabular}

Table 2. Selected bond lengths ( $\AA$ ) and bond angles (degrees) in the structure $\left[\mathrm{Co}(\mathrm{L})_{6}\right]\left(\mathrm{NO}_{3}\right)_{2}$.

\begin{tabular}{|c|c|c|c|}
\hline Bond & $d, \AA$ & Bond & $d, \AA$ \\
\hline $\mathrm{Co}(1)-\mathrm{N}(1) \neq 1$ & $2.1588(6)$ & $C(2)-N(3)$ & $1.3436(10)$ \\
\hline $\mathrm{Co}(1)-\mathrm{N}(1) \neq 2$ & $2.1589(6)$ & $\mathrm{C}(2)-\mathrm{H}(2)$ & $0.933(14)$ \\
\hline $\mathrm{Co}(1)-\mathrm{N}(1) \neq 3$ & $2.1589(6)$ & $\mathrm{N}(3)-\mathrm{C}(4)$ & $1.3702(12)$ \\
\hline $\mathrm{Co}(1)-\mathrm{N}(1) \neq 4$ & $2.1589(6)$ & $\mathrm{N}(3)-\mathrm{H}(3)$ & $0.873(19)$ \\
\hline $\mathrm{Co}(1)-\mathrm{N}(1)$ & $2.1589(6)$ & $\mathrm{C}(4)-\mathrm{C}(5)$ & $1.3663(12)$ \\
\hline $\mathrm{Co}(1)-\mathrm{N}(1) \neq 5$ & $2.1590(6)$ & $\mathrm{C}(4)-\mathrm{H}(4)$ & $0.912(16)$ \\
\hline $\mathrm{N}(1)-\mathrm{C}(2)$ & $1.327(9)$ & $\mathrm{C}(4)-\mathrm{H}(5)$ & $0.937(15)$ \\
\hline $\mathrm{N}(1)-\mathrm{C}(5)$ & $1.3826(10)$ & $\mathrm{O}(2)-\mathrm{N}(4)$ & $1.2547(6)$ \\
\hline Angle & $\omega, \operatorname{deg}$ & Angle & $\omega, \operatorname{deg}$ \\
\hline $\mathrm{N}(1) \neq 1-\mathrm{Co}(1)-\mathrm{N}(1) \neq 2$ & $91.76(2)$ & $\mathrm{N}(1)-\mathrm{C}(2)-\mathrm{N}(3)$ & $111.44(7)$ \\
\hline $\mathrm{N}(1) \neq 1-\mathrm{Co}(1)-\mathrm{N}(1) \neq 3$ & $88.24(2)$ & $\mathrm{N}(2)-\mathrm{C}(2)-\mathrm{H}(2)$ & $126.5(9)$ \\
\hline $\mathrm{N}(1) \neq 2-\mathrm{Co}(1)-\mathrm{N}(1) \neq 3$ & 180.0 & $\mathrm{~N}(3)-\mathrm{C}(2)-\mathrm{H}(2)$ & $122.0(9)$ \\
\hline $\mathrm{N}(1) \neq 1-\mathrm{Co}(1)-\mathrm{N}(1) \neq 4$ & 180.0 & $\mathrm{C}(2)-\mathrm{N}(3)-\mathrm{C}(4)$ & $107.65(7)$ \\
\hline $\mathrm{N}(1) \neq 2-\mathrm{Co}(1)-\mathrm{N}(1) \neq 4$ & $88.25(2)$ & $\mathrm{C}(2)-\mathrm{N}(3)-\mathrm{H}(3)$ & $123.9(12)$ \\
\hline $\mathrm{N}(1) \neq 3-\mathrm{Co}(1)-\mathrm{N}(1) \neq 4$ & $91.75(2)$ & $\mathrm{C}(2)-\mathrm{N}(3)-\mathrm{H}(3)$ & $128.4(12)$ \\
\hline $\mathrm{N}(1) \neq 1-\mathrm{Co}(1)-\mathrm{N}(1)$ & $88.25(2)$ & $\mathrm{C}(5)-\mathrm{C}(4)-\mathrm{N}(3)$ & $106.02(7)$ \\
\hline $\mathrm{N}(1) \neq 2-\mathrm{Co}(1)-\mathrm{N}(1)$ & $88.25(2)$ & $\mathrm{C}(5)-\mathrm{C}(4)-\mathrm{H}(4)$ & $131.6(10)$ \\
\hline $\mathrm{N}(1) \neq 3-\mathrm{Co}(1)-\mathrm{N}(1)$ & $91.75(2)$ & $\mathrm{C}(4)-\mathrm{C}(5)-\mathrm{N}(1)$ & $109.53(7)$ \\
\hline $\mathrm{N}(1) \neq 4-\mathrm{Co}(1)-\mathrm{N}(1)$ & $91.75(2)$ & $\mathrm{C}(4)-\mathrm{C}(5)-\mathrm{H}(5)$ & $129.5(9)$ \\
\hline $\mathrm{N}(1) \neq 1-\mathrm{Co}(1)-\mathrm{N}(1) \neq 5$ & $91.75(2)$ & $\mathrm{N}(1)-\mathrm{C}(5)-\mathrm{H}(5)$ & $120.9(9)$ \\
\hline $\mathrm{N}(1) \neq 2-\mathrm{Co}(1)-\mathrm{N}(1) \neq 5$ & $91.75(2)$ & $\mathrm{O}(2)-\mathrm{N}(4)-\mathrm{O}(2) \neq 6$ & $119.999(1)$ \\
\hline $\mathrm{N}(1) \neq 3-\mathrm{Co}(1)-\mathrm{N}(1) \neq 5$ & $88.25(2)$ & $\mathrm{O}(2)-\mathrm{N}(4)-\mathrm{O}(2) \neq 7$ & $120.000(1)$ \\
\hline $\mathrm{N}(1) \neq 4-\mathrm{Co}(1)-\mathrm{N}(1) \neq 5$ & $88.24(2)$ & & \\
\hline $\mathrm{N}(1)-\mathrm{Co}(1)-\mathrm{N}(1) \neq 5$ & 180.0 & & \\
\hline$C(2)-N(1)-C(5)$ & $105.35(6)$ & & \\
\hline $\mathrm{C}(2)-\mathrm{N}(1)-\mathrm{Co}(1)$ & $123.63(5)$ & & \\
\hline
\end{tabular}




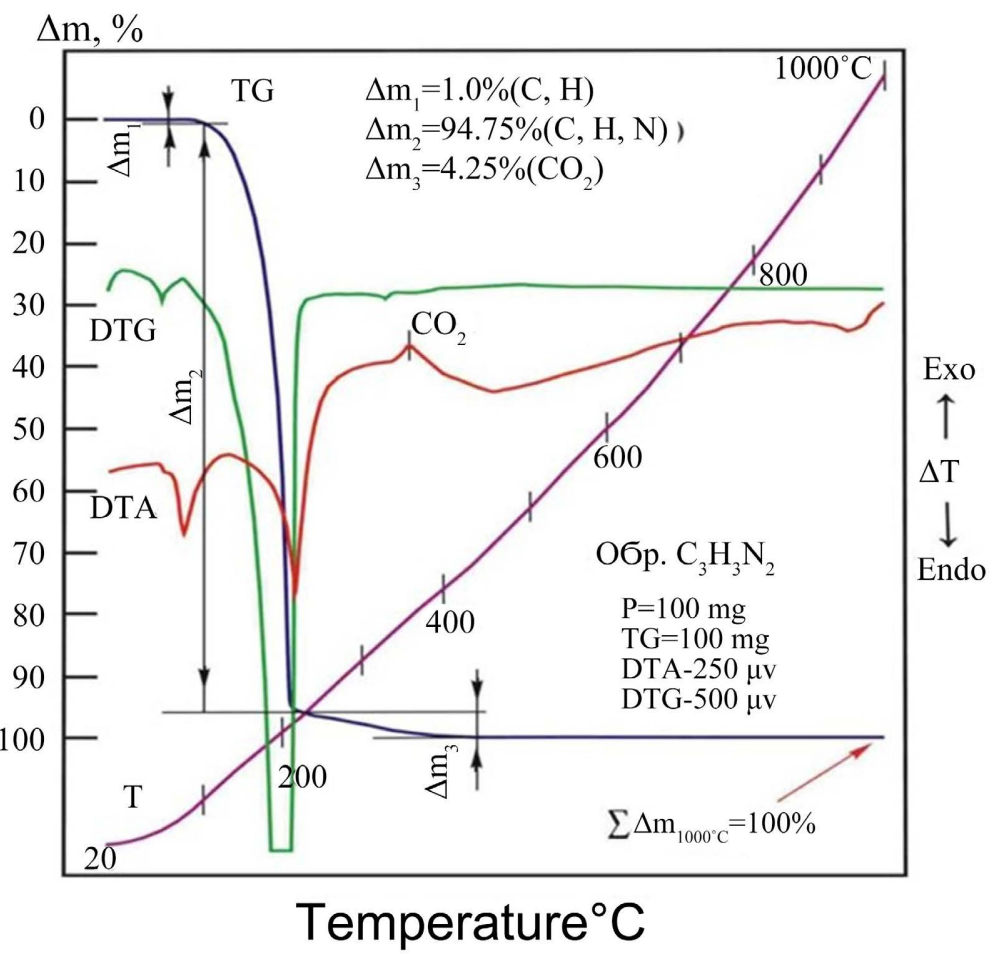

Figure 2. $\mathrm{C}_{3} \mathrm{H}_{4} \mathrm{~N}_{2}$ complex thermogram.

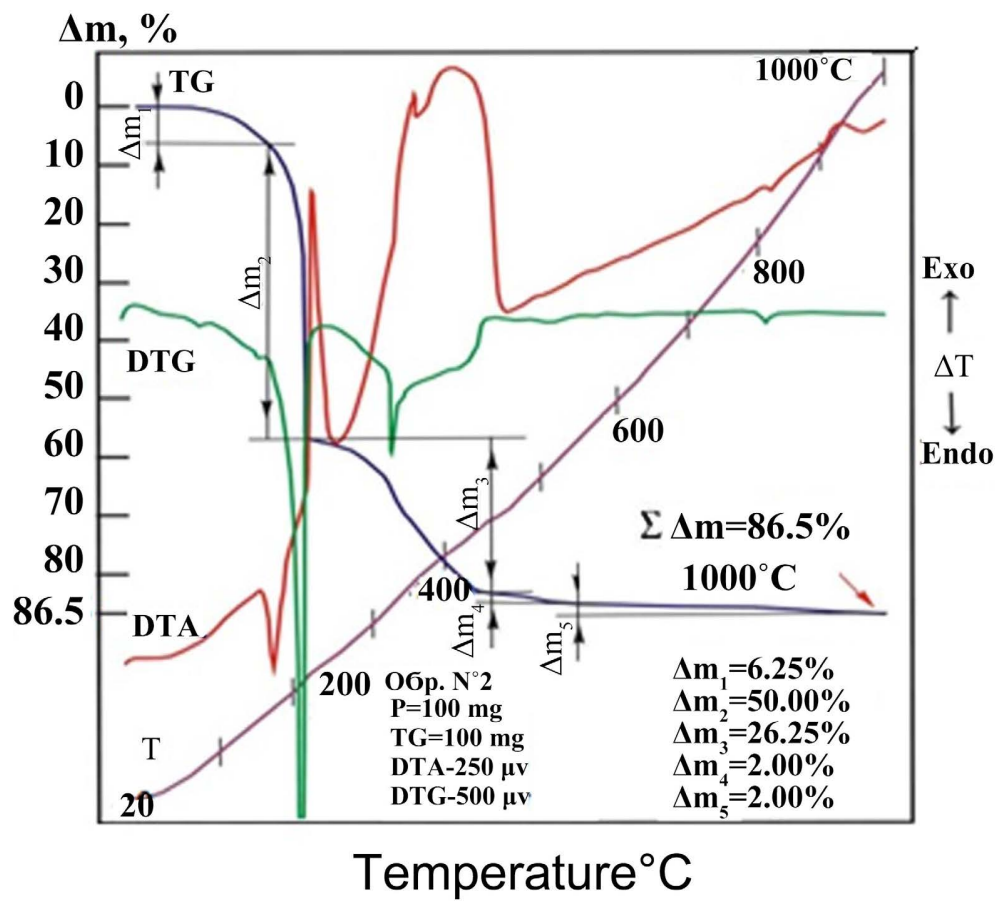

Figure 3. $\left[\mathrm{Co}(\mathrm{L})_{6}\right]\left(\mathrm{NO}_{3}\right)_{2}$ complex thermogram.

The TG curve of the complex records three stages of weight loss. The first $\left(70^{\circ} \mathrm{C}-170^{\circ} \mathrm{C}\right)$ corresponds to the removal of weakly bound guest water molecules. The second $\left(220^{\circ} \mathrm{C}-445^{\circ} \mathrm{C}\right)$, due to the actual thermal destruction of the complex, reflects the most intense weight loss (50.00\%). Differentiation of the 


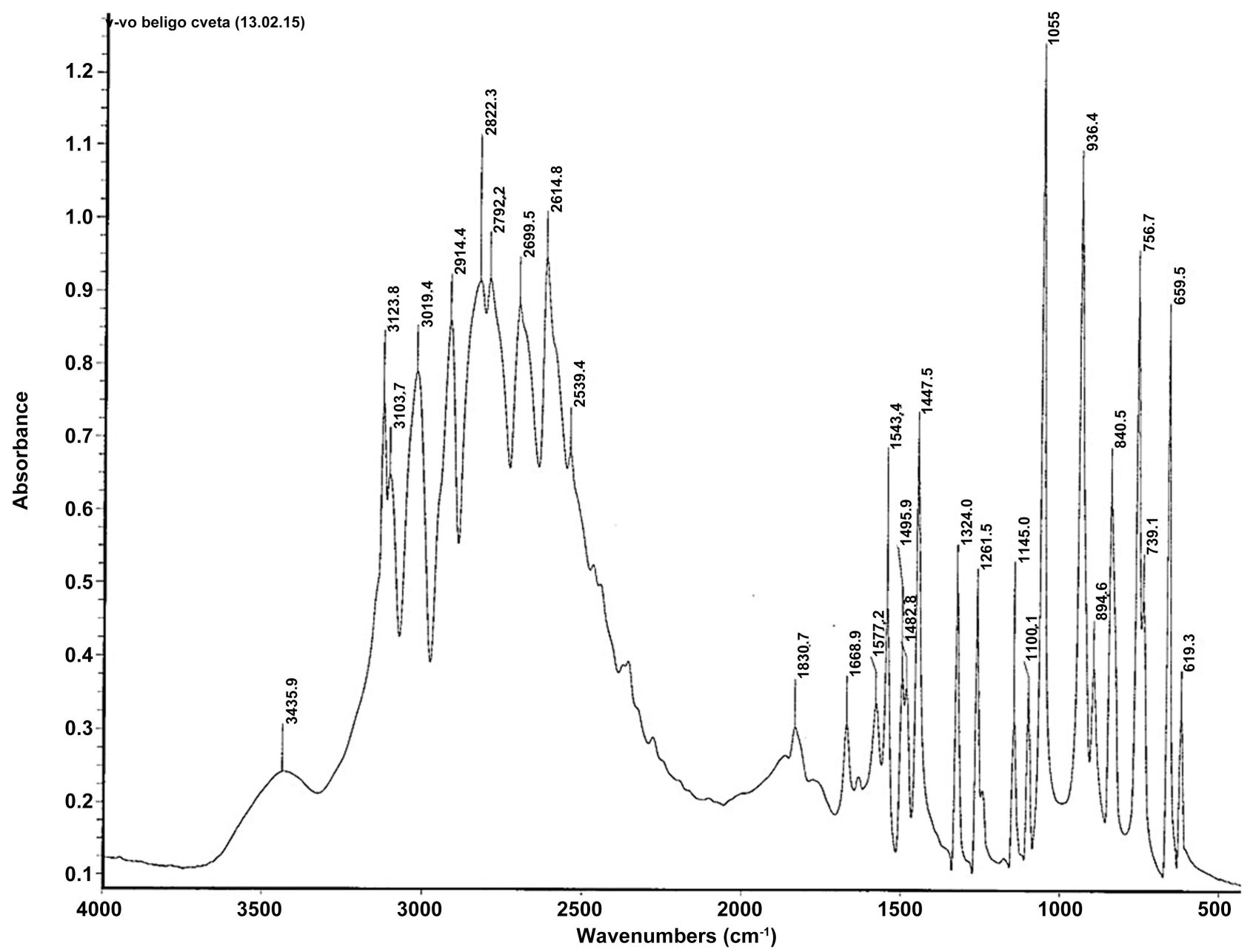

TG curve made it possible to establish that the maximum rate of weight loss falls on $300^{\circ} \mathrm{C}$. Subsequent, weakly expressed stages are associated with the desorption of thermolysis products. The residual product is CoO.

Based on the study of the IR spectrum of pure imidazole (Figure 4), it was revealed that stretching vibrations of the cyclic $\mathrm{C}=\mathrm{N}$ and $\mathrm{C}-\mathrm{N}$ bonds of the imidazole molecule correspond to a series of absorption bands in the frequency range 1670 - 1577, 1543 - 1261, and $1261-1324 \mathrm{~cm}^{-1}$. The appearance of highfrequency absorption bands at 1668 and $1577 \mathrm{~cm}^{-1}$ is due to stretching vibrations of C-N bonds of the imidazole ring. Intense bands at 1495, 1482, 1447, 1325, $1055 \mathrm{~cm}^{-1}$ correspond to stretching vibrations of the imidazole ring. Bands within $1261-940 \mathrm{~cm}^{-1}$ are characteristic of deformation vibrations of C-C, N-C and $\mathrm{C}-\mathrm{H}$ groups. Strong bands in the range of $740-890 \mathrm{~cm}^{-1}$ correspond to out-of-plane deformation vibrations of $\mathrm{C}-\mathrm{H}$ groups.

In the IR spectrum of the complex (Figure 5), changes occur in the region of vibrations of the main functional groups: the absorption bands of stretching vibrations of conjugated bonds $v(\mathrm{C}=\mathrm{C})$ and $v(\mathrm{C}=\mathrm{N})$ disappear, a high-frequency shift occurs by $\left(25-30 \mathrm{~cm}^{-1}\right)$, the intensity of the stretching vibration of the

Figure 4. IR spectrum of imidazole. 


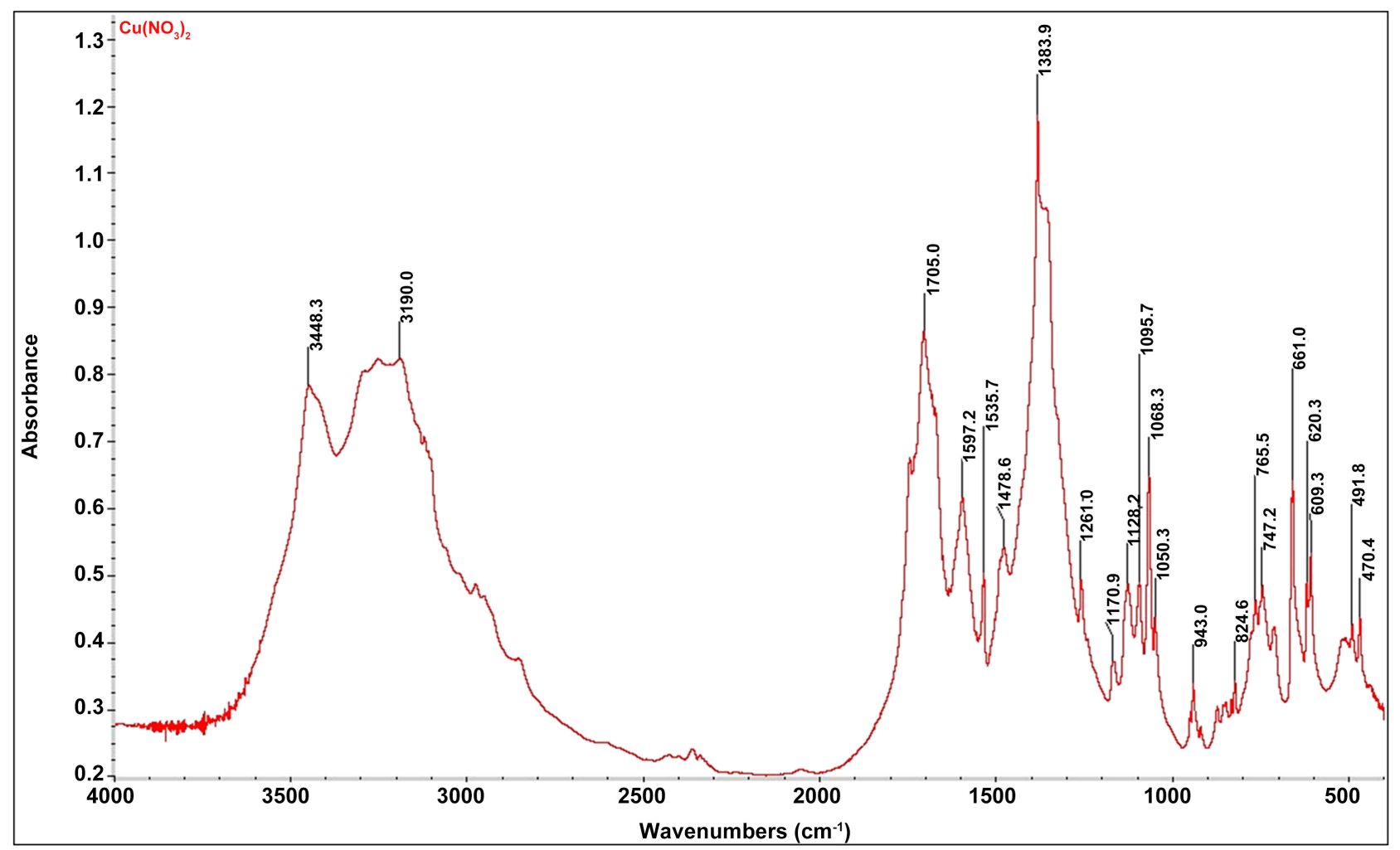

Figure 5. IR absorption spectrum of $\left[\mathrm{Co}(\mathrm{L})_{6}\right]\left(\mathrm{NO}_{3}\right)_{2}$ complex.

azole ring at $1480-1580 \mathrm{~cm}^{-1}$ and new frequencies $v($ co-N) appear at $455-590$ $\mathrm{cm}^{-1}$. From this, it follows that the complex undergoes monodentate coordination of the imidazole molecule through the pyridine nitrogen atom $\mathrm{N}(3)$, which is confirmed by X-ray diffraction data.

The crystal and molecular structure of the $\left[\mathrm{Co}(\mathrm{L})_{6}\right]\left(\mathrm{NO}_{3}\right)_{2}$ complex, which crystallizes in the trigonal system with the space group R-3, has been determined by $\mathrm{X}$-ray diffraction. The lattice parameters are: $a=12.3555(10), b=12.3555(10), c$

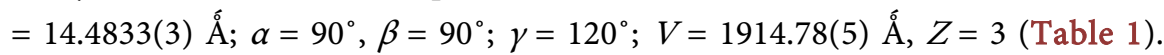
The structure of the complex consists of discrete $\left[\mathrm{Co}(\mathrm{L})_{6}\right]^{2+}$ cations and $\mathrm{NO}_{3}^{-}$ anions. The $\mathrm{Co}^{2+}$ ion has a centrosymmetric octahedron configuration with a coordination site- $\mathrm{CoN}_{6}$ (Figure 1). Imidazole ligand molecules are coordinated through the pyridine nitrogen atom $\mathrm{N}(3)$ to the $\mathrm{Co}^{2+}$ ion with an average Co $\cdots \mathrm{N}$ bond distance of 2.1590 Á.

In the octahedral complex $\left[\mathrm{Co}(\mathrm{L})_{6}\right]\left(\mathrm{NO}_{3}\right)_{2}$ three trans angles are $180^{\circ}$ in symmetry, and the remaining angles vary from $88.24(2)$ to $91.76(2)^{\circ}$ (Table 2). The Co-N bond distance is as follows: a short $\mathrm{Co}(1)-\mathrm{N}(1)$ bond $=2.1588(6)$ and a long $\mathrm{Co}(1)-\mathrm{N}(1)$ bond $=2.1592(2)$. The chelate cycle of the complex is flat, with an average deviation of $0.0015(2)$ Á. Opposite imidazole rings are centrosymmetric. Adjacent imidazole rings are almost perpendicular to each other with dihedral angles of $85.25(2), 91.75(2)$, and $88.25(2)^{\circ}$, which minimizes steric effects between these rings. In the crystal structure, all imidazole $\mathrm{N}-\mathrm{H}$ groups, nitrate ions contribute to the formation of hydrogen bonds. The number of intermole- 
cular contacts with a hydrogen bond, including $\mathrm{N}-\mathrm{H}$ groups and $\mathrm{NO}_{3}^{-}$anions, connect the cations into layers in the ab plane. The $\left[\mathrm{Co}\left(\mathrm{C}_{3} \mathrm{H}_{4} \mathrm{~N}_{2}\right)_{6}\right]^{2+}$ cations, in turn, are linked by $\mathrm{NO}_{3}^{-}$anions, forming a three-dimensional network of hydrogen bonds, which stabilizes the crystal structure of the $\left[\mathrm{Co}\left(\mathrm{C}_{3} \mathrm{H}_{4} \mathrm{~N}_{2}\right)_{6}\right]\left(\mathrm{NO}_{3}\right)_{2}$ complex.

\section{Conclusion}

In summary, we determined structure of $\left[\mathrm{Co}(\mathrm{L})_{6}\right]\left(\mathrm{NO}_{3}\right)_{2}$ complex, in which number of intermolecular contacts with a hydrogen bond, including $\mathrm{N}-\mathrm{H}$ groups and $\mathrm{NO}_{3}^{-}$anions, connect the cations into layers in the ab plane. Imidazole ligand molecules are coordinated through the pyridine nitrogen atom $\mathrm{N}(3)$ to the $\mathrm{Co}^{2+}$ ion. As a result of biological screening, it was established that the $\left[\mathrm{Co}(\mathrm{L})_{6}\right]\left(\mathrm{NO}_{3}\right)_{2}$ complex has a fungicidal effect on the Candida bacterial culture. The development is protected by a patent of the Kyrgyz Republic (No. 2211 dated June 9, 2020).

\section{Conflicts of Interest}

The authors declare no conflicts of interest in the publication of this paper.

\section{References}

[1] Reiss, A., Cioateră, N., Dobrițescu, A., Rotaru, M., Carabet, A.C., Parisi, F., Gănescu, A., Dăbuleanu, I., Spînu, C.I. and Rotaru, P. (2021) Bioactive Co(II), Ni(II), and $\mathrm{Cu}$ (II) Complexes Containing a Tridentate Sulfathiazole-Based (ONN) Schiff Base. Molecules, 26, Article No. 3062.

[2] Gaber, A., Refat, M.S., Belal, A.A.M., El-Deen, I.M., Hassan, N., Zakaria, R., Alhomrani, M., Alamri, A.S., Alsanie, W.F. and Saied, E.M. (2021) New Mononuclear and Binuclear $\mathrm{Cu}(\mathrm{II}), \mathrm{Co}(\mathrm{II}), \mathrm{Ni}(\mathrm{II})$, and $\mathrm{Zn}(\mathrm{II})$ Thiosemicarbazone Complexes with Potential Biological Activity: Antimicrobial and Molecular Docking Study. Molecules, 26, Article No. 2288.

[3] Saltykova, M.S., Yelchischeva, Y.B., Chekanova, L.G., Mokrushin, I.G. and Pavlov, P.T. (2020) Complex Forming Properties of Diacylhydrazines of Neopentanic Acid with Ions $\mathrm{Cu}$ (II), Co (II) and Ni (II) in Ammonia Media. Perm University Bulletin, Series: Chemistry, 10, 159-168. https://doi.org/10.17072/2223-1838-2020-2-159-168

[4] Razzoqova, S.R., Kadirova, S.A., Ashurov, J.M., Rakhmonova, D.S., Ziyaev, A.A. and Parpiev N.A. (2019) 5-(3-hydroxyphenyl)-1,3,4-oxadiazole-2(3H)-thione Hemi-Hydrate. Journal the International Union of Crystallography (IUCr) Data, 4, Article ID: x1915322019. https://doi.org/10.1107/S2414314619015323

[5] Bureekaew, S., Shimomura, S. and Kitagawa, S. (2008) Chemistry and Application of Flexible Porous Coordination Polymers. Science and Technology of Advanced Materials, 9, Article ID: 014108. https://doi.org/10.1088/1468-6996/9/1/014108

[6] Luconi, L., Tuci, G., Yakhvarov, D., Poli, G., Rossin, A., Khusnuriyalova, A. and Giambastiani, G. (2019) Imidazole-Bridged Tetrameric Group (IV) Heteroleptic Complexes from the Spontaneous Metal-Ligand Assembly of a Potentially $\mathrm{N}_{4}$-Tetradentate Ligand. European Journal of Inorganic Chemistry, 2019, 4384-4393. https://doi.org/10.1002/ejic.201900763

[7] Anosov, V.Y., Ozerova, M.I. and Fialkov, Y.A. (1976) Fundamentals of Physical and 
Chemical Analysis. AN SSSR, Nauka, Moscow, Leningrad, 503 p.

[8] Emhoff, K.A., Balaraman, L., Simpson, S.R., Stromyer, M.L., Kalil, H.F., Beemiller, J.R., Philipp, S., Teya, S.E., Ahmed, M.H.S., Michael, A.D., Matthew, J.P., Wiley, J.Y. and Christopher, W.B. (2018) Synthesis and Characterization of Cobalt (II) $N, N^{p}$ Diphenylazodioxide Complexes. ACS Omega, 3, 16021-16027.

https://doi.org/10.1021/acsomega.8b01200

[9] Bruker (2019) APEX III. Bruker AXS Inc., Madison, Wisconsin, USA.

[10] Krause, L., Herbst-Irmer, R., Sheldrick, G.M. and Stalke, D. (2015) Comparison of Silver and Molybdenum Microfocus X-Ray Sources for Single-Crystal Structure Determination. Journal of Applied Crystallography, 48, 3-10.

https://doi.org/10.1107/S1600576714022985

[11] Sheldrick, G.M. (2015) SHELXT Integrated Space-Group and Crystal-Structure Determination. Acta Crystallography, A71, 3-8. https://doi.org/10.1107/S2053273314026370

[12] Sheldrick, G.M. (2015) Crystal Structure Refinement with SHELXL. Acta Crystallography, 71, 3-8. 